\title{
УПРАВЛЕНЧЕСКИЙ ПОДХОД ЭФФЕКТИВНОГО МЕНЕДЖЕРА В МУЗЫКАЛЬНОМ ИСКУССТВЕ
}

\section{MANAGERIAL APPROACH OF AN EFFECTIVE MANAGER IN THE MUSICAL ART}

\section{Rodionova Yu. Mindlin}

Summary. Understanding the essence of management in the cultural and artistic sphere as a management process, the author emphasizes that in modern scientific thought, first of all, the concepts of "coordination" and "management" are not differentiated. Despite the fact that the term "management" is analogous to " coordination ", there is a widespread opinion that they are not identical, since the concept of "coordination"is somewhat broader than "management". From the point of view of a systematic approach to theatrical activity, the author gives this definition: it is a system of interaction between theater employees and the audience, which is formed on the basis of reflecting reality, which includes the processes of creating, distributing, perceiving and evaluating performances.

The author has proved that the management system in musical theaters must, on the one hand, meet all the requirements of the material product management system, on the other hand, have features taking into account the specificity of the final product. This factor should be taken into account when drawing up and developing a strategy for the development of a cultural institution.

Keywords: coordination, management in the field of art, art management, management of musical theaters, profitability, marketing in the field of art.

B ажнейшими сферами общественного развития российского социума являются три: политическая, экономическая и культурная. Этим обусловлены и три главные виды социального управления:

- социально-политический менеджмент (индустриально-государственное управление);

- социально-экономический менеджмент (управление материальным производством);

- социально-культурный менеджмент (управление духовным производством).

При этих условиях радикальное реформирование общества, его трансформация и модернизация требуют совершенствования всех видов социального управления,
Родионова Дарья Геннадьевна

Кандидат культурологии, Российская академия музыки имени Гнесиных sunshila@yandex.ru

Миндлин Юрий Борисович

К.э.н., доцент, Московская государственная академия ветеринарной медицины и биотехнологии имени им. К.И. Скрябина mindliny@mail.ru

Аннотация. Осмысливая сущность менеджмента культурно-художественной сферы как управленческого процесса, автор делает акцент на том, что в современной научной мысли, прежде всего, не разграничены понятия «управление» и «менеджмент». Несмотря на то, что термин «менеджмент» является аналогом «управление», распространенное мнение 06 их нетождественности, поскольку понятие «управление» несколько шире, чем «менеджмент». С позиций системного подхода, театральной деятельности автор дает такое определение: это система взаимодействия работников театра и зрительской аудитории, что складывается на основе отражения действительности, что включает процессы создания, распространения, восприятия и оценки спектаклей.

Авторами доказано, что система управления в музыкальных театрах должна быть, с одной стороны, соответствовать всем требованиям системы менеджмента материальным продуктом, с другой стороны — иметь особенности сучетом специфичности конечного продукта. Этот фактор необходимо учитывать при составлении и разработке стратегии развития культурного учреждения.

Ключевые слова: менеджмент, менеджмент в сфере искусства, арт-менеджмент, управление музыкальными театрами, прибыльность, маркетинг в сфере искусства.

в частности, управления культурно-творческой сферой, которой принадлежит особое место в нашем обществе.

Во-первых, культура обнаруживает состояние нравственного здоровья социума, экономических и политических свобод, его духовный потенциал. Во-вторых, благодаря культуре сочетаются традиции и опыт прошлого с настоящим, намечаются тенденции будущего развития. Именно культура способна не только активизировать, но и тормозить общественные процессы, гармонизировать их во время трансформаций. В-третьих, русская культура отождествляет ценности, нормы и идеалы, которые играют конструктивную и регулятивную роль в обществе. В-четвертых, культура способствует форми- 
рованию целостного образа жизни, продуцирует общие для нации ценности, символы и смыслы, которые сохраняют и развивают национальную идентичность. В-пятых, в условиях глобализации только целостная, разнообразная отечественная культура способна противостоять нивеляционным, дегуманизационным воздействиям глобального масскульта.

Менеджмент культурно-художественной сферы (от лат. management - управление) рассматривают как процесс планирования организации, мотивации, контроля и координации, направленный на достижение определенной цели в социокультурной деятельности с помощью профессионально подготовленных к этому специалистов [5].

Важно отметить, что, как массовое явление в области общей теории управления, менеджмент поставь результате осуществления управленческой революции на западе в 60-80-х годах XX века.

Как составляющая социального управления, современная парадигма менеджмента культурно-художественной сферы предполагает, во-первых, активное внедрение как научно-аналитических подходов в управлении, так и стратегического целевого управления; во-вторых, усиление централизованного государственного управления в регулировании духовно-культурных отношений, а вместе с тем - усиление регионального, муниципального управления и самоуправления; в-третьих, формирование действенной системы отбора, подготовки и использования профессиональных управленческих кадров [10].

Формирование менеджмента культурно-художественной сферы в современных условиях осуществляется на других принципах, чем это было при советском времени. В первую очередь, управление больше опирается на саморазвитие и активность граждан, на идеологический плюрализм, консенсус и толерантность как залог рационального и творческого участия граждан в социокультурной жизни общества. Управление в этих обстоятельствах приобретает иное содержание - вместо силовой административной регламентации культурных процессов оно направлено на поддержку культуры, а это требует не только активного осмысления, но и изменения его стиля, культуры управления в целом.

Реформирование системы управления отраслью культуры, создание механизма правовой регламентации и вмешательства государства в культурные процессы, формирование правовой и экономической базы для деятельности негосударственных культурных институций, развитие рыночных структур во многих секторах куль- туры - это главные направления менеджмента культурно-художественной сферы.

Менеджмент культурно-художественной сферы является органической составляющей государственного управления, он опирается на определенную методологию (от греч. metodas - путь, способ познания, logos - учение, слово), которая содержит, с одной стороны, систему наиболее общих принципов, положений и методов как основу научных знаний по управлению культурно-творческой сферой, а с другой,- совокупность приемов, способов и процедур исследование механизма управления [2].

Менеджмент в культурно-художественной сфере осуществляется согласно общим функциям управления:

во-первых, - планирование, в процессе которого определяется и детализируется цель функционирования и развития всей культурно-художественной инфраструктуры, поэтапность и сроки реализации и распределения ресурсных возможностей;

во-вторых,- формирование структуры органов государственной власти и органов местного самоуправления, учреждений культуры и т.п., а также обеспечения всем необходимым для их нормальной работы (персоналом, материалами, оборудованием, финансовыми ресурсами и т.д.). В рамках функции планирования важно четко определить роль государственных учреждений и организаций в культурной деятельности, цели и задачи, стратегию деятельности, что обеспечит основу для эффективной структуры;

в-третьих, - мотивация, в процессе которой осуществляется побуждение и активизация работников культуры к результативной деятельности и достижения цели. Путем материального и морального стимулирования работников культуры, обогащение содержания их труда создаются необходимые условия для выявления их творческого потенциала и дальнейшего развития;

в-четвертых, контроль, во время которого на основе наблюдения, проверки всех сторон деятельности, учета и анализа оцениваются количественные и качественные показатели результатов деятельности государственных учреждений, организаций, заведений культуры. Наконец, функция координации, которая предполагает объединение и гармонизацию действий по достижению организационных целей (согласованная работа всех подразделений культурной инфраструктуры путем рациональных связей коммуникаций между ними) [6].

В теории менеджмента культурно-художественной сферы, ключевое значение имеют основные методоло- 
гические принципы (исходные положения) - объективность и историзм.

Принцип объективности направляет исследования на осмысление объективных закономерностей, тенденций, которые определяют процессы культурно-художественного развития.

Актуализируется система факторов как положительных, так и отрицательных. Объективность духовно-культурных знаний предполагает, что процесс их получения соответствует реальной действительности, законам познания, независимым от человека. Объективность научных выводов основывается на доказательности научных фактов. Принцип историзма требует осмысления процесса управления культурно-художественной сферой в конкретно-исторических обстоятельствах, во взаимосвязи всех его субъектов. Важно оценивать генезис его исторических моделей, содержание их структурных компонентов, эволюцию и тенденции развития [9].

Менеджмент культурно-художественной сферы является целенаправленной и упорядоченной взаимодействием между субъектом и объектом. Субъектами здесь предстают [11]:

- государство в лице уполномоченных органов исполнительной власти;

- территориальные общины в лице органов местного самоуправления;

- работники культуры;

- учреждения культуры, а также предприятия, учреждения и организации всех форм собственности - уставами (положениями) которых предусмотрено осуществление деятельности в сфере культуры и тому подобное,- наделенных государственно-властными полномочиями.

Субъекты обеспечивают реализацию интересов определенной социальной общности (народа, слои, нации, этнической группы); каждый из них имеет определенные функции, которые отражающие общесистемное разделение труда; в соответствии со спецификой государственных органов, субъекты управления имеют общие и отличительные признаки по уровню и формам организованности; каждый из субъектов управления приобретает общесистемной признаки, находясь только в рамках системы управления и взаимоотношений с соответствующими объектами или другими субъектами этой системы, или с другими системами управления.

Объектом менеджмента является структурированная целостная культурно-художественная сфера, функционирующая под направляющим воздействием субъектов с целью достижения общих целей системы управления: внедрение программно-целевого метода управления, принципов прозрачности, публичности, системности, эффективности, инновационности.

\section{Система менеджмента охватывает [7]:}

во-первых, культурную деятельность сообществ и групп, которые являются носителями духовно-культурных представлений, ценностей, стилей и норм поведения, потребителями и производителями культурных благ;

во-вторых, институциональная структура (культурно-образовательные и культурно-досуговые учреждения и организации, формальные и неформальные творческие объединения, союзы, движения и т. п), в рамках которой разворачиваются культурно-художественные процессы в российском обществе в целом;

в-третьих, отрасли культуры, которые функционируют на профессиональных и любительских началах - художественная литература, кинематограф, театральное, музыкальное, хореографическое, пластическое, изобразительное и декоративно-прикладное искусство, архитектура, фотоискусство, дизайн, народное творчество и тому подобное.

Сюда же следует отнести такие отрасли культуры, как охрана культурного наследия, архивное и библиотечное дело, книгоиздания, создания и распространения фонограммной и аудиовизуальной продукции, художественно-художественное образование, специальная культурно-художественное образование, международные культурные связи и прочее.

Объекты управления культурно-художественной сферы имеют такие признаки [8]:

- закрепление их правового статута в специальных правовых актах;

- тесное и органичное сочетание, как управленческих функций, так и функций производства культурной продукции и предоставления культурных услуг;

- предоставление широкой сферы самостоятельной культурной деятельности на основе саморегулирования;

- определение функциональной подчиненности объектов-организаций вышестоящим органам;

- объектам обеспечения гарантий участия в решении задач на всех уровнях управления.

Менеджмент культурно-художественной сферы как составляющая государственного управления имеет следующие признаки:

- организационное и исполнительно-распорядительный характер деятельности; 
- в процессе реализации управленческой деятельности осуществляются функции государства в культурно-художественной области;

- обеспечивается его функционирование уполномоченными на то субъектами управления;

- подконтролен и подзаконен;

- имеет государственно-властный характер.

Арсенал исследовательских средств и инструментов теории менеджмента культурно-художественной сферы можно разделить на три группы [3]:

- общенаучные методы (абстрагирования, аналогии, классификации);

- теоретические методы (системный анализ, структурно-функциональный анализ, ситуационный подход, исторический подход, диалектический метод;

- гипотетически-дедуктивный метод, сравнительный метод и т. п); эмпирические (бихевиористические) методы: контент-анализ документов и информационных потоков; эксперимент;

- анкетный опрос и т.д.

Осмысливая сущность менеджмента, следует обратить внимание на то, что на состояние и перспективы развития механизма управления в культурной сфере влияют следующие факторы [8]:

- во-первых, общемировые тенденции развития менеджмента;

- во-вторых, динамика социокультурных реалий российского общества, обусловлена трансформационными процессами;

- в-третьих, массовое применение новейших информационно-коммуникационных технологий.

Ученые рассматривают менеджмент культурно-художественной деятельности как составляющую единой системы государственного управления, на которую возложена задача контроля и правового, а в рамках действующего законодательства и административного регулирования межкультурных отношений. В структуре культурно-художественного менеджмента, который осуществляет контрольно-регулятивные функции в сфере общественных отношений, выделяют, с определенной степенью условности, несколько уровней воздействия на сферу его компетенции. Прежде всего, это стратегический уровень на высшем законодательном и исполнительном уровнях государства (Президент, Парламент, Министерства). Второй уровень, тактический, который включает разработку конкретных методов, мероприятий, подходов и средств реализации принятых решений. Этим занимаются соответствующие структуры в Министерстве культуры РФ и в центральных правительственных учреждениях. Наконец, третий уровень - это местное управление, на котором происходит собственно реализация государственной культурно-художественной политики в субъектах федерации, и отслеживаются результаты выполнения предыдущих заданий, поручений, решений. Эта работа осуществляется региональными подразделениями органов государственного управления.

За последние годы проблемой развития и организации театрального процесса в новых условиях существования занимались такие научные исследователи: И.Д.Безгин, В.И. Ковтуненко, Н.И. Кичурчак, А.М.Семашко, которые освещали в своих работах главные вопросы, которые стоят перед деятелями современного российского театра и анализировали их приспособления к сегодняшней реальности в контексте творческо-организационных отношений.

В течение последнего времени особенно чувствуется необходимость исследований театрального искусства, как особой системы социальной деятельности, связанной не только с искусством, но и с организацией деятельности творческих коллективов, с производством, сохранением и распространением художественных ценностей. Все это обусловлено переходом российской экономики на новый этап развития, масс-медийный охват зрительской аудитории (что стало главным конкурентом театра), незначительная поддержка государства и другие условия, которые поставили сложные проблемы перед деятелями российских театров.

По своей сути театр не является прибыльным производством, поэтому часто подвергался к рассмотрению на закрытие и многочисленным статьям, однако что театр находится на стадии «вымирания». Надо отметить, что, не смотря на сложные условия существования современного театра, находятся новые вспомогательные знания для творческих и организационно-экономических отношений. Одними из таких знаний являются навыки в области маркетинга и менеджмента. Сначала эти отрасли кажутся маловлиятельными на зрелищное искусство, но на самом деле являются неотъемлемыми и необходимыми в современности для полноценного существования и развития театрального процесса.

Мы исходим из понимания того, что маркетинг и менеджмент сценических искусств обладает присущей ему спецификой и потому не может быть до конца идентифицирован с менеджментом и маркетингом, в других сферах хозяйственно-экономической жизни общества. С прагматической точки зрения экономиста, менеджером может быть человек, который объединяет труд и капитал для получения конечного продукта. Для социолога театральным менеджером может быть лицо, которое способно влиять на поведение работников. То есть, менеджер - это человек, который принимает участие 
в планировании, организации, комплектовании штата, инспектировании, контроле.

По словам И.Д.Безгина: «Идеальному менеджеру театрального проекта не обязательно иметь степень доктора или огромный опыт работы в экономике или театральном менеджменте. Идеальный менеджер для идеи - это, прежде всего, тот, кто осознает ее и заставляет работать на нее других» [1].

Поэтому можно обобщить, что эта профессия должна не только систематизировать и организовывать, но и обогащать творческий опыт и сохранять идейность театра.

Менеджмент не очень почитается среди профессиональных художников и работников государственного сектора, причем все отчетливей становится разделение на тех, кто считает опыт делового администрирования необходимыми профессиональными навыками, и тех, по мнению которых, это дань моде. Такая точка зрения является типичной для культурно-художественной среды, в частности потому, что менеджеры часто получают больше актеров или музыкантов, от которых они зависят. Культурная политика, которая делает приоритетом поддержку художников, экономя на менеджменте, на первый взгляд, кажется довольно привлекательной.
Сделаем вывод о том, что без помощи менеджеров художники не смогли бы выполнить большую часть задуманного или же сделали бы это менее эффективно. Незаметная работа по планированию, мобилизации дополнительных средств (фандрейзинг), управление персоналом, мониторинга и маркетинга добавляет стоимость художественному продукту. Спектакль может быть гениальной, но без маркетинга и дистрибуции о них никто не узнает - не увидит и не прочитает. Социально-экономический капитал культуры невозможно использовать без качественного менеджмента. Именно от него в значительной степени зависит эффективное и результативное использование имеющихся ресурсов, а от рекламы зависит зрительский спрос [7].

За рубежом профессия менеджера театральных проектов стала привычной в театральном деле, владение ею присуще не только отдельным лицам, но и, прежде всего, директорам и режиссерам театра. В России эти знания только начинают использоваться в профессиональном театре, поэтому требуют более глубокого изучения и заимствования опыта иностранных государств. Такая организационно-экономическая система будет способствовать дальнейшему развитию и легкому существованию профессионального российского музыкального театра в условиях рыночной экономики.

. Безгин И. Д. Искусство и рынок: Очерки. - К.: ВВП «Компас», 2005.— 254 с.

2. Гапонов Е. И. Театральное дело в историко-экономическом контексте эпохи: учебное пособие.- Электрон. текстовые данные.— Москва, Екатеринбург: Кабинетный ученый, 2013.— 152 c.—URL: http://www.iprbookshop.ru/48282.html.

3. Дадамян Г. Условия рынка и театральный менеджер // Сцена.— М., 2011.— № 6. - С. 22-23.

4. Забенькин Н. Культурно-зрелищные организации: школа выживания // Ежемесячная Всерос. музыкально-информационная газета «Играем сначала. Dа capo al fine». 2009. С. 18-19

5. Зайцева 0.С. Менеджмент культуры и искусства. Театр // Современная культурология: проблемы и перспективы. — Саратов: Издательство «Саратовский источник», 2016. - С. 12-15.

6. Искусство театра: Вчера. Сегодня. Завтра: выпуск 7 / Р. И. Архангельская [и др.].— Электрон. текстовые данные.— Москва, Екатеринбург: Кабинетный ученый, 2013.—C. 21.—URL: http://www.iprbookshop.ru/47986.html.

7. Лэнгли С. Театральный менеджмент и продюсерство. Американский опыт // Перевод с англ. под ред. И. Д. Безгина. — К.: ВВП «Компас», 2010.— С. 45-46

8. Митина И. Д., Мартыненко А. В., Моисеева М. В. Анализ и интерпретация произведений культуры в контексте культурологического подхода: учеб. пособие. Ульяновск: УлГУ, 2013.—- 129

9. Моисеева М.В., Коростелкина Т. А. Арт-менеджмент в театральной сфере: сущность, специфика, этапы, проблемы // Симбирский научный вестник.Ульяновск: Ульяновский государственный университет, 2014.— № 3 (17). — С. 80-86.

10. Тульчинский Г.Л. Менеджмент в сфере культуры. СПб., 2001. С. 117

11. Шабалина Т. Театр (театральное искусство) / Энцикл. «Кругосвет».— URL: http://www.krugosvet.ru.

๑ Родионова Дарья Геннадьевна ( sunshila@yandex.ru ), Миндлин Юрий Борисович ( mindliny@mail.ru ). Журнал «Современная наука: актуальные проблемы теории и практики» 